\title{
Evaluation of Quality Protein Maize Variety under Integrated Uses of Different Fertilizer Sources in Jimma, South Western Ethiopia
}

\author{
Sisay Gurmu* Muhidin Biya Eshetu Yadete \\ Jimma Agricultural Research Center, P. O. Box 192, Jimma, Ethiopia
}

\begin{abstract}
Studies on the combined use of organic and inorganic fertilizers for maize are lacking at Jimma conditions. Therefore, a field experiment was conducted to determine the effect of integrated uses of organic with inorganic fertilizers sources on productivity of quality protein maize (QPM) variety BHQPY545 at Kersa, Omonada woreda and Jimma on station, Southwestern Ethiopia during 2016 and 2017 main cropping seasons and one year validation at Omonada woreda. The experiment involved factorial combinations of inorganic and organic fertilizer with negative control, $150 \mathrm{~kg} \mathrm{ha}^{-1} \mathrm{NPSZnB}+140 \mathrm{~kg} \mathrm{ha}^{-1}$ urea top dressed, recommended $\mathrm{NP}_{2} \mathrm{O}_{5}(92 / 69$ $\mathrm{kg} \mathrm{ha}^{-1}$ ), 100\% compost, $25 \%$ compost $+75 \%$ recommended NP, $50 \%$ compost $+50 \%$ recommended NP, $75 \%$ compost $+25 \%$ recommended NP and 100\% compost $+100 \%$ recommended NP fertilizer which was laid out in randomized complete block design (RCBD). The compost was added based on N equivalency of recommended fertilizer rate. Data on yield and yield components of maize were subjected to ANOVA using SAS version 9.3. The over location and year highest grain yield $\left(8443 \mathrm{~kg} \mathrm{ha}^{-1}\right)$ and above ground biomass $\left(21.52 \mathrm{t} \mathrm{ha}^{-1}\right) \mathrm{was}$ obtained from $100 \%$ compost $+100 \%$ recommended NP fertilizer. Partial budget analysis revealed $100 \%$ compost $+100 \%$ recommended NP fertilizer realized the maximum net return $(39,718$ ETB) with marginal rate of return (94\%). From farmers decision point and current on farm input availability and technical feasibility and economic analysis, 92/69 $\mathrm{kg} \mathrm{ha}^{-1} \mathrm{~N} / \mathrm{P}_{2} \mathrm{O}_{5}$ fertilizer application taken as optimal fertilizer application and recommended for production of BHQPY545 in Jimma area and other similar humid agro-ecologies of southwestern Ethiopia.
\end{abstract}

Keywords: Grain yield, inorganic fertilizer, organic fertilizer, recommended fertilizer rate, soil health.

DOI: $10.7176 /$ ALST/88-01

Publication date:July $31^{\text {st }} 2021$

\section{Introduction}

Maize is the primary staple crop in Ethiopia and plays an important role in the livelihood of the people of Ethiopia. Its availability and abundance determines the level of welfare and food security in the country. In Ethiopia, future increases in maize production to meet domestic demand will have to rely on improvements in yield per hectare rather than on the expansion of maize production area. Enhanced maize productivity can be achieved by increased use of modern production techniques such as the adoption of hybrid maize varieties, the use of chemicals and integrated nutrient management. Small-scale maize production plays a major role in Ethiopia maize economy and adoption of hybrid technology by small-scale farmers would have the potential to address sustainability and supply issues.

Most soils contain an abundance of elements essential for the plants development, but majority of these elements are rarely available for plant use due to nutrient loss. Nutrient depletion and soil degradation have become serious threat to agricultural productivity in Ethiopia. These soils suffered multi-nutrient deficiencies, application of mineral fertilizers has become mandatory to increase crop yields in such soils (Adeniyan and Ojeniyi, 2005).

The dissemination and adoption of QPM is lagging behind normal maize in Sub-Saharan Africa where it is needed more (Aman et al., 2016). Twumasi-Afriyie et al. (2016) reported that an estimated area of one million ha of land in Sub Saharan Africa (SSA) was under QPM production in 2015. Research on QPM is of recent history in Ethiopia. The work was started by testing introduced CIMMYT (International Maize and Wheat Improvement Center) QPM pools and populations in 1980 (Leta et al., 2001). From experimental variety trials conducted at some locations in Ethiopia, for instance, some QPM entries yielded 9.5 ton ha ${ }^{-1}$, which is an advantage of $20 \%$ over the best local check (Gemechu et al., 2016).

Among plant nutrients nitrogen is a vitally important, a major yield determining nutrient and its availability in sufficient quantity throughout the growing season is essential for optimum maize growth (Kogbe and Adediran, 2003). It is a component of protein, nucleic acids and other compounds essential for plant growth process (Onasanya et al., 2009). Whereas phosphorus is the second most important nutrient element (after nitrogen) limiting agricultural production (Kogbe and Adediran, 2003). It is used for growth, utilization of sugar and starch, photosynthesis, metabolic process which leads to higher yield of the crop (Ayub et al., 2002).

Compost is one of the organic fertilizers and it is an alternative source of plant nutrients (Vanlauwe et al., 
2012; Ngwira et al., 2013). Application of compost improves soil fertility parameters, such as alleviates acidification, benefits better microbial activity, soil aeration, increase soil organic matter, increases CEC, P availability and sustainable increase in crop yields (Diacono and Montemurro, 2010). Use of compost and sometimes in combination with inorganic fertilizers gave maximum grain yields of QPM (Balai et al. 2011).

Currently, the lack of balanced and integrated application of nutrients reduced the yield potential of QPM and other maize varieties in most maize producing areas of Ethiopia. The productivity of maize is low as a result of continuous cropping, inadequate use of fertilizer inputs, very low or lack of the use of organic manure neither alone nor in combinations with mineral fertilizers. Since, the use of inorganic fertilizer in maize production is costly and its effect is short term, there is another option to use organic fertilizer in integrated form. For this, site specific testing of Integrated Nutrient Management (INM) is becoming critical and sorting out of optimum nutrients for maize production that benefit farmers to get better nutrition and economic advantage and sustain soil health. Therefore, site specific INM investigation based on growth, yield and yield related parameters of QPM variety under agro-climatic conditions of Jimma, Southwestern Ethiopia is needed. Even though the cultivar was under production, the cultivar performance under the use of NPS fertilizer and compost has not been tested

Hence, for better dissemination and adoption of QPM hybrid there is a need to understand its performance with various agronomic management practices, of which nutrient management is vital in influencing the growth and yield of the crop. Therefore, the objective of this paper was to evaluate the integrated uses of organic with inorganic fertilizers sources on productivity of QPM maize variety and economic feasibility.

\section{Materials and Methods}

\subsection{Description of the Experimental Site}

The experiment was conducted at Jimma zone (Kersa, Omonada woreda and Jimma on station), in Oromiya region at the southwestern part of Ethiopia, during the main cropping season of 2016 and 2017. Although, at 2018 main cropping season a validation experiment was done at Omonada woreda. The average maximum and minimum temperature is $9^{\circ} \mathrm{C}$ and $28^{\circ} \mathrm{C}$ respectively and reliably receives good rains up to $1747 \mathrm{~mm}$ per annum. The farming system of the study sites is dominated with coffee and cereal crops like maize, teff and sorghum The areas has warm and cold climate with convenient topography which is very suitable for all agricultural practices. It was situated in the tepid to cool humid-mid highlands of southwestern Ethiopia. The soil type of the experimental area was Eutric nitisols (reddish brown).

\subsection{Treatments and Experimental Design}

The experimental field was ploughed and prepared following the conventional tillage practice before planting at all experimental locations. Two maize seeds were planted per hill and then thinning was done after the good establishment of seedlings so as to maintain a single healthy plant per hill. There were eight inorganic and organic fertilizers with negative Control (no input):1)blended NPSZnB $150 \mathrm{kgha}^{-1}+140 \mathrm{~kg} \mathrm{ha}^{-1}$ urea top dressed, 2) recommended NP (92/69 $\mathrm{kg} \mathrm{ha}^{-1}$ ) (as check), 3) 100\% Compost based on $\mathrm{N}$ equivalency of recommended fertilizer rate (RFR), 4) $25 \%$ compost based on N equivalency of RFR $+75 \%$ Recommended NP, 5) $50 \%$ compost based on N equivalency of RFR $+50 \%$ Recommended NP, 6) $75 \%$ compost based on N equivalency of RFR $+25 \%$ Recommended NP, and 7) $100 \%$ compost based on N equivalency of RFR $+100 \%$ recommended NP fertilizer. Medium maturing maize variety BHQPY545 was used for the study. It was released by Bako Agricultural Research Center through the National Maize Research Program in 2008. It performs well in agroecology of 1000-2000 m.a.s.l with rainfall of 1000-1200 mm. It can give 8.0-9.5 and 5.5-6.5 t ha-1 grain yields under on-station and on-farm experiments, respectively. It was moderately tolerant to rust, blight and gray leaf spot with maturity date of 138 and $25 \mathrm{~kg} \mathrm{ha}^{-1}$ seed rate. The Randomized complete Block Design (RCBD) with three replications and plot size $22.95 \mathrm{~m}^{2}(4.5 \mathrm{~m} \times 5.1 \mathrm{~m})$ for each treatment was used.

Nitrogen fertilizer rates were applied in a split in such a way that half during planting and half at the knee height growth stage to increase the nitrogen use efficiency. All other agronomic practices were applied uniformly to all experimental plots as per their respective recommendations for maize in the study area.

2.3. Data collection: The data collected were yield, yield related and other agronomic data were collected.

\subsection{Data analysis}

Analysis of variance (ANOVA) for all collected data was computed using SAS version 9.3 statistical software. Whenever the ANOVA results showed the significant differences between sources of variation, the means were separated using least significant difference (LSD). The homogeneity of variance test was done as suggested by Gomez and Gomez, (1984). 


\subsection{Partial budget analysis}

Partial budget analysis was performed to investigate the economic feasibility of the treatments and assess the costs and benefits associated with different chemical fertilizer and compost levels. The partial budget technique as described by CIMMYT (1988) was applied. The partial budget analysis was done using the prevailing market prices for inputs at planting and for outputs at the time the crop was harvested. All costs and benefits were calculated on a per hectare basis in Ethiopian Birr (ETB). The inputs and/or concepts used in the partial budget analysis were the mean grain yield of each treatment, the gross field benefit (GFB) ha ${ }^{-1}$ (i.e., the product of field price and the mean yield for each treatment), the field price of NP fertilizer (including blended fertilizer) and urea (the nutrient cost plus the cost of transportation from the point of sale to the farm), cost of labor spent on compost preparation, transportation and incorporation, the total costs that varied (TVC) which included the sum of field costs of fertilizers and their application.

The net benefit (NB) was calculated as the difference between the GFB and the TVC. The marginal rate of return (MRR \%) were also calculated. To obtain an estimate of these returns the MRR (\%) was calculated as changes in NB divided by changes in cost. Thus, a minimum acceptable MRR of $100 \%$ was used; indicating for every one ETB expended, there is a return of one ETB for a given variable input (CIMMYT, 1988), which is suggested to be realistic. This enables the farmer to make recommendations from marginal analysis. The dominance analysis procedure as detailed in CIMMYT (1988) was used to select potentially profitable treatments from the range that was tested. Sensitivity analysis for different interventions was also carried out to test the recommendation made for its ability to withstand price changes. Sensitivity analysis simply implied redoing marginal analysis with the alternative prices. Through sensitivity analysis, maximum acceptable field price of an input was calculated with the minimum rate of return as described by Shah et al. (2009).

\section{Results and Discussions}

\subsection{Soil and Compost Physico-chemical Properties}

The soil of the experimental field and compost were characterized for selected physico-chemical properties before the application of the treatments (Table 1). The average soil $\mathrm{pH}$ of the trial sites ranged from 4.97 to 5.12 , which was strongly acidic (Batjes, 1995); and it is ideal for the production of most field crops. The $\mathrm{pH}$ of the soil affects maize growth by suppressing the root development and reducing availability of macronutrients to plants especially phosphorus (Brady and Weil, 2008). The soil total $\mathrm{N}$ ranged from 0.14 to $0.22 \%$ and OC from 1.47 to $2.17 \%$. These were found to be a medium rate for crop growth and development for both nutrients (Berhanu, 1980). The Bray II extractable available P for Omonada woreda was $4.38 \mathrm{mg} \mathrm{kg}^{-1}$, which is below the critical level $\left(8 \mathrm{mg} \mathrm{kg}^{-1}\right)$ for most crop plants whereas, Kersa and Jimma on station sites ranged from 18.16 to $30.14 \mathrm{mg}$ $\mathrm{kg}^{-1}$ which is high in content as described by Tekalign and Haque (1991).

Table 1 Selected physico-chemical properties of the soil of the experimental sites and compost before planting

\begin{tabular}{lcccc}
\hline Characters & \multicolumn{3}{c}{ Soil } & Compost \\
\cline { 2 - 4 } & Kersa & Omonada & Jimma on station & \\
\hline pH(1:2.5) & 4.97 & 5.12 & 5.11 & 9.05 \\
av P(ppm) & 30.14 & 4.38 & 18.16 & 508.66 \\
TN $(\%)$ & 0.22 & 0.16 & 0.14 & 0.60 \\
OC $(\%)$ & 2.17 & 1.94 & 1.47 & 7.12 \\
OM $(\%)$ & 3.73 & 3.34 & 2.53 & 12.27 \\
C:N ratio & 9.92 & 12.09 & 10.33 & 11.80 \\
\hline
\end{tabular}

Where $\mathrm{pH}=$ hydrogen ion concentration, $\mathrm{OC}=$ organic carbon, $\mathrm{TN}=$ Total Nitrogen, Av. $\mathrm{P}=\mathrm{Available}$ phosphorous, $\mathrm{OM}=$ Organic matter. Values are the means of duplicated samples.

The chemical compositions of the compost utilized as organic source of soil fertility amendment in this study are presented in Table 1. Accordingly, the mean OC and total $\mathrm{N}$ contents of the compost was $7.12 \%$ and $0.60 \%$ respectively, with a resultant narrow $\mathrm{C}: \mathrm{N}$ ratio of 11.80 . It indicates that the prepared compost was well decomposed to the level of average soil organic matter. The $\mathrm{C}: \mathrm{N}$ ratio of about 30 is considered $\mathrm{N}$ neutral, lower ratios will release $\mathrm{N}$ and act as $\mathrm{N}$ fertilizers and higher ratios will immobilize $\mathrm{N}$ as microbial breakdown of the carbon component. The C:N ratio of compost should drop below 20\% before application to the soil (Brady and Weil, 2002) to have expected impact from application of compost. The $\mathrm{pH}$ of compost (9.05) was strongly alkaline and it is capable of ameliorating the acidic content of the soil (Onwudiwe et al., 2014).

\subsection{Effect of organic and inorganic fertilizer on growth, yield and yield components of Maize}

The combined analysis over locations and seasons showed fertilizer types and rates highly significantly $(\mathrm{P}<0.01)$ influenced plant height, ears per plant, lodging percentage, grain yield and above ground biomass. But the harvest index was not significantly $(\mathrm{P}>0.05)$ affected by the fertilizer types and rates (Table 2$)$.

\subsubsection{Plant height}

Numerically the longest plant height $(268.8 \mathrm{~cm})$ was recorded from $100 \%$ recommended NP+100\% compost, 
while the shortest plant height $(216.5 \mathrm{~cm})$ was recorded from the control (Table 2). The plant height was increased by $24.2 \%$ at full recommended NP fertilizer and full compost as compared to control. The increase in plant height with increasing rate of NP fertilizer and compost could be due to their synergistic effects. Nitrogen promotes the formation of chlorophyll which in turn resulted in higher photosynthetic activity, vigorous vegetative growth and taller plants and $\mathrm{P}$ is required for shoot and root development where metabolism is high and cell division is rapid (Rao et al., 2001). Also the compost acted as a store house of different plant nutrients, reduce $\mathrm{P}$ fixation, and improve $\mathrm{CEC}$, aeration, root penetration and water storage capacity of the soil (Rahman et al., 2012). These results were in line with the findings of Adekayode and Ogunkoya (2010) who explained that there was very high significant difference in maize plant height in plots treated with high fertilizers compared with nil application.

\subsubsection{Number of ears per plant}

The maximum number of ears per plant (1.63) was recorded from $100 \%$ compost $+100 \%$ recommended NP fertilizer, which was statistically at par with all treatments except the control and $100 \%$ compost only, while the minimum number of ears per plant (1.02) was recorded from the control (Table 2). The $100 \%$ compost $+100 \%$ recommended NP fertilizer increased 59.8\% number of ears per plant over control. Number of ear per plant was determined by prolific ability of the BHQPY545 maize variety as described by Adefris et al. (2015) and the growth behavior of the crop which is dependent upon management practices and edaphic and climatic factors. The improvement of the soil conditions or enrichment with nutrients and organic matter due to soil-added materials might be responsible for better cob production under plots treated with NP fertilizer and compost. This is considered as a main yield component as it defines the yield potential of a crop. The improvement of the soil conditions or enrichment with nutrients and organic matter due to soil-added materials might be responsible for better cob production under plots treated with NP fertilizer and compost. These results were in line with the findings of Dagne (2016) who indicated that the application of blended fertilizer increased the number of cobs harvested compared to the control plot. Also, Amanullah et al. (2015) found that application of compost was most beneficial in terms of higher yield and yield components of maize over the control.

\subsubsection{Lodging percent}

The highest lodging percent $(21.84 \%)$ was recorded from the control which was not statistically significant different from $100 \%$ compost, while the lowest lodging percent $(7.21 \%)$ was recorded from blended NPSZnB $150 \mathrm{~kg} \mathrm{ha}^{-1}+140 \mathrm{~kg} \mathrm{ha}^{-1}$ urea top dressed fertilizer. The latter was statistically at par with the following recommended compositions: 1) NP fertilizer, 2) $25 \%$ compost $+75 \%$ recommended NP, 3) $50 \%$ compost $+50 \%$ recommended NP and 4) 100\% compost $+100 \%$ recommended NP (Table 2). The application of blended NPSZnB fertilizer decreased lodging by 202.9 percent over the control. Nevertheless, increasing NP and compost fertilizer linearly increased resistance of plants for lodging. Moreover, the number of data points with higher lodging percentage was more for treatments that received lower fertilizer rates than treatments with relatively higher fertilizer rates. Brady and Weil (2000) reported that plants deficient in nutrient develop thin and spindly stems. Such stems could be susceptible for lodging by wind. Moreover, N deficient plants have poor development of root system, which reduces their anchorage capacity.

\subsubsection{Grain yield}

Numerically the highest grain yield $\left(8443 \mathrm{~kg} \mathrm{ha}^{-1}\right)$ was recorded from $100 \%$ compost $+100 \%$ recommended NP fertilizer at which it was statically at par with recommended $\mathrm{N} / \mathrm{P}_{2} \mathrm{O}_{5}$ fertilizer $\left(92 / 69 \mathrm{~kg} \mathrm{ha}^{-1}\right)$ and $25 \%$ compost + $75 \%$ recommended NP fertilizer. On the other hand, the lowest grain yield $\left(3436 \mathrm{~kg} \mathrm{ha}^{-1}\right)$ was obtained from the control (Table 2). The grain yield advantages of $145.7 \%$ and $118.6 \%$ were recorded from $100 \%$ compost $+100 \%$ recommended NP fertilizer and recommended N/ $\mathrm{P}_{2} \mathrm{O}_{5}$ fertilizer $\left(92 / 69 \mathrm{~kg} \mathrm{ha}^{-1}\right)$ respectively when compared to the negative control. Reduction of grain yield in unfertilized plots might be due to nutritional imbalance and deficiency of certain important plant growth elements at various significant growth stages. The increase in grain yield could be attributed to beneficial influence of yield contributing characters and increase of the nutrients in the soil and modification of soil environments that resulted in better vegetative growth which in turn enabled the crop to produce greater photo-assimilate.

$\mathrm{N}$ has synergistic effects on growth and yield attributes resulting in greater translocation of photosynthates from source to sink, beneficial effect on physiological process, plant metabolism and growth (Yayock et al., 1988) and there by leading to higher grain yield. The P supply is particularly important for stimulating early root formation and growth, functions in plant macromolecular structures as a component of nucleic acids and phospholipids (Marschner 2012). Mugwe et al. (2007) reported the higher grain yield of maize was recorded in treatments of compost either alone or in combination with mineral fertilizer when compared to the control. Moreover, compost is responsible in improving soil physical, chemical and microbial conditions in addition to giving different macro and micro nutrient to the plant.

These results were in line with findings of N'Dayegamiye et al. (2010) who reported that application of compost with $120 \mathrm{~kg} \mathrm{~N}^{-1}$ led to higher maize grain yields. The highest grain yield was recorded with application of farm yard manure $10 \mathrm{tha}^{-1}+100 \%$ RDF in QPM maize hybrid, which was significantly superior 
to the other treatments as revealed by Ravi et al. (2012).

Table 2 Over seasons and locations main effect of organic and inorganic fertilizer on yield and yield components of QPM maize variety during 2016 and 2017 cropping season

\begin{tabular}{|c|c|c|c|c|c|c|}
\hline \multirow[b]{2}{*}{ Fertilizer types and rates } & \multicolumn{5}{|c|}{ Over location and year } & \multirow[b]{2}{*}{$\mathrm{HI}$} \\
\hline & $\begin{array}{l}\text { Plant } \\
\text { height }(\mathrm{cm})\end{array}$ & EPP & $\begin{array}{l}\text { Lodging } \\
\%\end{array}$ & $\begin{array}{l}\text { Grain yield } \\
\left(\mathrm{kg} \mathrm{ha}^{-1}\right)\end{array}$ & $\begin{array}{l}\text { AGB } \\
\left(\mathrm{t} \mathrm{ha}^{-1}\right)\end{array}$ & \\
\hline Negative Control & $216.5 d$ & $1.02 \mathrm{c}$ & $21.84 \mathrm{a}$ & $3436 d$ & $9.53 \mathrm{~d}$ & 0.38 \\
\hline $\begin{array}{l}150 \mathrm{~kg} \mathrm{ha}^{-1} \mathrm{NPSZnB}+140 \mathrm{~kg} \mathrm{ha}^{-1} \\
\text { Urea top dressed }\end{array}$ & $244.7 b c$ & $1.57 \mathrm{a}$ & $7.21 \mathrm{c}$ & $7284 b$ & $17.86 b$ & 0.48 \\
\hline $\operatorname{Rec} \operatorname{NP}\left(92 / 69 \mathrm{~kg} \mathrm{ha}^{-1}\right)$ & $236.2 \mathrm{c}$ & $1.55 \mathrm{a}$ & $8.48 b \mathrm{c}$ & $7509 \mathrm{ab}$ & $18.82 \mathrm{ab}$ & 0.51 \\
\hline $100 \%$ Compost & $237.61 b c$ & $1.25 \mathrm{~b}$ & $20.51 \mathrm{a}$ & $4991 c$ & $13.77 \mathrm{c}$ & 0.39 \\
\hline $25 \%$ compost $+75 \%$ Rec NP & $250.8 \mathrm{~b}$ & $1.52 \mathrm{a}$ & $9.19 b c$ & $7384 \mathrm{ab}$ & $18.37 \mathrm{ab}$ & 0.41 \\
\hline $50 \%$ compost $+50 \%$ RecNP & $250.8 b$ & $1.55 \mathrm{a}$ & $11.32 \mathrm{bc}$ & $7032 b$ & $19.47 \mathrm{ab}$ & 0.38 \\
\hline $75 \%$ compost $+25 \%$ Rec NP & $248.4 \mathrm{bc}$ & $1.53 \mathrm{a}$ & $13.20 \mathrm{~b}$ & $7057 b$ & $18.60 \mathrm{ab}$ & 0.40 \\
\hline $100 \%$ compost $+100 \% \operatorname{Rec} \mathrm{NP}$ & $268.8 \mathrm{a}$ & $1.63 \mathrm{a}$ & $9.49 \mathrm{bc}$ & $8443 a$ & $21.52 \mathrm{a}$ & 0.41 \\
\hline $\operatorname{LSD}(0.05)$ & 13.33 & 0.159 & 4.978 & 1148 & 3.198 & 0.140 \\
\hline CV (\%) & 8.28 & 16.58 & 35.67 & 19.21 & 18.13 & 20.62 \\
\hline F-test & $* *$ & $* *$ & $* *$ & $* *$ & $* *$ & NS \\
\hline
\end{tabular}

$* \mathrm{LSD}=$ Least significant difference; $\mathrm{CV}=$ Coefficient of variation; Rec $=$ Recommended; $\mathrm{EPP}=$ Ears per plant; $\mathrm{HI}=$ Harvest index; $\mathrm{AGB}=$ Above ground biomass; Values followed by the same letter within a column are not significantly different at $\mathrm{P}<0.05$. Compost was applied based on $\mathrm{N}$-equivalence of recommended fertilizer rate $\left(92 \mathrm{~N} \mathrm{~kg} \mathrm{ha}^{-1}\right)$

\subsubsection{Aboveground biomass yield}

The highest above ground biomass $21.52 \mathrm{t} \mathrm{ha}^{-1}$ was recorded from $100 \%$ compost $+100 \%$ recommended NP fertilizer at which it was statically at par with the following: 1)recommended $\mathrm{N} / \mathrm{P}_{2} \mathrm{O}_{5}$ fertilizer $\left.\left(92 / 69 \mathrm{~kg} \mathrm{ha}{ }^{-1}\right), 2\right)$ $25 \%$ compost $+75 \%$ recommended NP fertilizer, 3) $75 \%$ compost $+25 \%$ recommended NP and 4) $50 \%$ compost $+50 \%$ recommended NP fertilizer. On the other hand, the lowest above ground biomass $9.53 \mathrm{tha} \mathrm{w}^{-1} \mathrm{was}$ obtained from the control (Table 2). The above ground biomass yield advantage of $125.8 \%$ and $97.5 \%$ were recorded from $100 \%$ compost $+100 \%$ recommended NP fertilizer and recommended NP fertilizer respectively when compared to the negative control.

The result showed that the above ground biomass was increased by increasing rates of NP fertilizer and compost application due to higher number of ears per plant, plant height and grain yield. Adequate supply of nutrients to the crop helps in the synthesis of carbohydrates, which are required for the formation of protoplasm, thus resulting in higher cell division and cell elongation. Thus an increase in biomass yield might have been on account of overall improvement in the vegetative growth of the plant due to the application of NP fertilizer and in combination with compost. The above ground biomass improvement with compost, compared to results obtained with the control, was probably attributed to the improvement of the physical conditions and biological activity of the soil (Chang et al., 1990). Similar results were obtained by Makinde and Ayoola (2010) who reported that conjunctive application of organic and inorganic fertilizers is effective for the growth of maize and improving the yields.

\subsubsection{Harvest index}

The harvest index was not significantly $(\mathrm{P}>0.05)$ affected by fertilizer types and rates over locations and years (Table 2).

\subsection{Economic Analysis}

The open market price (6 birr kg-1) for maize crop and the official prices of chemical fertilizer $\left(13.5 \mathrm{birr} \mathrm{kg}^{-1}\right)$, urea $\left(10\right.$ birr kg $\left.^{-1}\right)$ and the cost of labor spent on compost preparation, transport and incorporation were used for analysis. The cost of application and transport for fertilizer was taken to be 15 birr $100 \mathrm{~kg}^{-1}$. Grain yield was adjusted by $10 \%$ for management difference to reflect the difference between the experimental yield and the yield that farmers could expect from the same treatment (Getachew and Taye, 2005, CIMMYT, 1988).

The dominance analysis procedure as detailed in CIMMYT (1988) was used to select potentially profitable treatments. Dominance analysis led to the selection of treatments ranked in increasing order of total variable costs (Table 3). For each pair of ranked treatments, the percent marginal rate of return (MRR) was calculated. The MRR (\%) between any pair of un-dominated treatments was the return per unit of investment in chemical fertilizer and plant population density. It was calculated by dividing the change in net benefit to the change in variable costs. $100 \%$ MRR means for every 1 birr invested in different cost of fertilizer and maize seed, farmers can expect to recover 1 birr and obtain an additional 1 birr (CIMMYT, 1988). 
Table 3 Partial budget with dominance analysis of organic and inorganic fertilizer maize grain yield at Jimma zone in 2016 and 2017 cropping season

\begin{tabular}{|c|c|c|c|c|c|c|}
\hline Fertilizer types and rates & $\begin{array}{ll}\begin{array}{l}\text { GY } \\
\left.h^{-1}\right)\end{array} & (\mathrm{kg} \\
\end{array}$ & $\begin{array}{l}\text { Adj.GY } \\
\left(\mathrm{kg} \mathrm{ha}^{-1}\right)\end{array}$ & $\begin{array}{l}\text { GFB (ETB } \\
\left.h^{-1}\right)\end{array}$ & $\begin{array}{l}\text { TVC (ETB } \\
\left.\text { ha }^{-1}\right)\end{array}$ & $\begin{array}{l}\text { NB } \\
\left.\text { ha }^{-1}\right)\end{array} \quad$ (ETB & $\begin{array}{l}\text { Domi } \\
\text { nance }\end{array}$ \\
\hline Negative Control & 3436 & 3092 & 18553 & 0 & 18553 & $\begin{array}{c}-- \\
-\end{array}$ \\
\hline $100 \%$ Compost $\left(9.2 \mathrm{t} \mathrm{ha}^{-1}\right)$ & 4991 & 4492 & 26951 & 2206 & 24745 & UD \\
\hline $75 \%$ compost $+25 \%$ Rec NP & 7057 & 6352 & 38109 & 2887 & 35222 & UD \\
\hline $\operatorname{Rec} \operatorname{NP}\left(92 / 69 \mathrm{~kg} \mathrm{ha}^{-1}\right)$ & 7509 & 6758 & 40550 & 3273 & 37277 & UD \\
\hline $\begin{array}{l}150 \mathrm{~kg} \mathrm{ha}^{-1} \text { NPSZnB }+140 \mathrm{~kg} \\
\mathrm{ha}^{-1} \text { Urea top dressed }\end{array}$ & 7284 & 6556 & 39335 & 3425 & 35910 & $\mathrm{D}$ \\
\hline $50 \%$ compost $+50 \%$ Rec NP & 7032 & 6329 & 37972 & 3448 & 34525 & $\mathrm{D}$ \\
\hline $25 \%$ compost $+75 \%$ Rec NP & 7384 & 6645 & 39873 & 4008 & 35864 & $\mathrm{D}$ \\
\hline $100 \%$ compost $+100 \%$ Rec NP & 8443 & 7599 & 45593 & 5875 & 39718 & UD \\
\hline
\end{tabular}

${ }^{*} \mathrm{GY}=$ Grain yield; $\mathrm{GFB}=$ Gross field benefit; $\mathrm{TCV}=$ Total cost that varied; $\mathrm{NB}=$ Net benefit; $\mathrm{D}=$ Dominated treatment; UD = Un-dominated treatments; ETB $=$ Ethiopian Birr; Price of chemical fertilizer $=13.5 \mathrm{birr} \mathrm{kg}^{-1}$; Price of Urea $=10$ birr kg-1 ; Wage rate $=30$ Birr man-day ${ }^{-1}$; Retail price of grain $=6$ birr kg ${ }^{-1}$

The highest net benefit $\left(39,718 \mathrm{ETB} \mathrm{ha}^{-1}\right)$ was obtained from $100 \%$ compost $+100 \%$ recommended NP fertilizer with un acceptable MRR 94\%. This was followed by a net benefit of $\left(37,277 \mathrm{ETB}^{-1} \mathrm{~h}^{-1}\right)$ with acceptable MRR 533\% by application of recommended NP fertilizer $\left(92 / 69 \mathrm{~kg} \mathrm{ha}^{-1}\right)$ (Table 4). The highest MRR 1538\% was obtained from application of $75 \%$ compost $+25 \%$ recommended NP fertilizer and it dramatically decreased when higher nutrients were applied from both compost and chemical fertilizer (Fig. 1). Thus, those treatments above the minimum acceptable marginal rate of return $(100 \%)$, could be recommended as alternative sources for users (CIMMYT, 1988).On other hand, the lowest net benefit (18,553 ETB) was obtained from control (no input). Due to application of recommended NP fertilizer $\left(92 / 69 \mathrm{~kg} \mathrm{ha}^{-1}\right)$, there was net benefit increase by $114.1 \%$ (21,164 ETB) when compared with negative control.

Table 4 Partial budget with estimated marginal rate of return (\%) of organic and inorganic fertilizer on maize grain yield at Jimma zone during 2016 and 2017 cropping season

\begin{tabular}{llllll}
\hline Treatments & $\begin{array}{l}\text { TVC } \\
\left.\mathrm{ha}^{-1}\right)\end{array}$ & $\begin{array}{l}\text { (ETB } \\
\text { NB (ETB ha } \\
\text { 1) }\end{array}$ & Raised cost & $\begin{array}{l}\text { Raised } \\
\text { benefit }\end{array}$ & MRR (\%) \\
\hline Negative Control & 0 & 18553 & --- & --- & --- \\
$100 \%$ Compost $\left(9.2 \mathrm{t} \mathrm{ha}^{-1}\right)$ & 2206 & 24745 & 2206 & 6192 & 281 \\
$75 \%$ compost $+25 \% \mathrm{Rec}^{-1} \mathrm{NP}$ & 2887 & 35222 & 681 & 10476 & 1538 \\
Rec NP $\left(92 / 69 \mathrm{~kg} \mathrm{ha}^{-1}\right)$ & 3273 & 37277 & 386 & 2055 & 533 \\
$100 \%$ compost $+100 \%$ Rec NP & 5875 & 39718 & 2602 & 2441 & 94 \\
\hline
\end{tabular}

${ }^{*} \mathrm{GY}=$ Grain yield; GFB $=$ Gross field benefit; TCV $=$ Total cost that varied; $\mathrm{NB}=$ Net benefit; $\mathrm{Rec}=$ Recommended; $\mathrm{D}=$ Dominated treatment; $\mathrm{UD}=\mathrm{Un}$-dominated treatments; $\mathrm{ETB}=$ Ethiopian Birr; Price of chemical fertilizer $=13.5 \mathrm{birr} \mathrm{kg}^{-1}$; Price of Urea $=10$ birr kg$^{-1}$; Wage rate $=30$ Birr man-day ${ }^{-1}$; Retail price of grain $=6$ birr kg-1

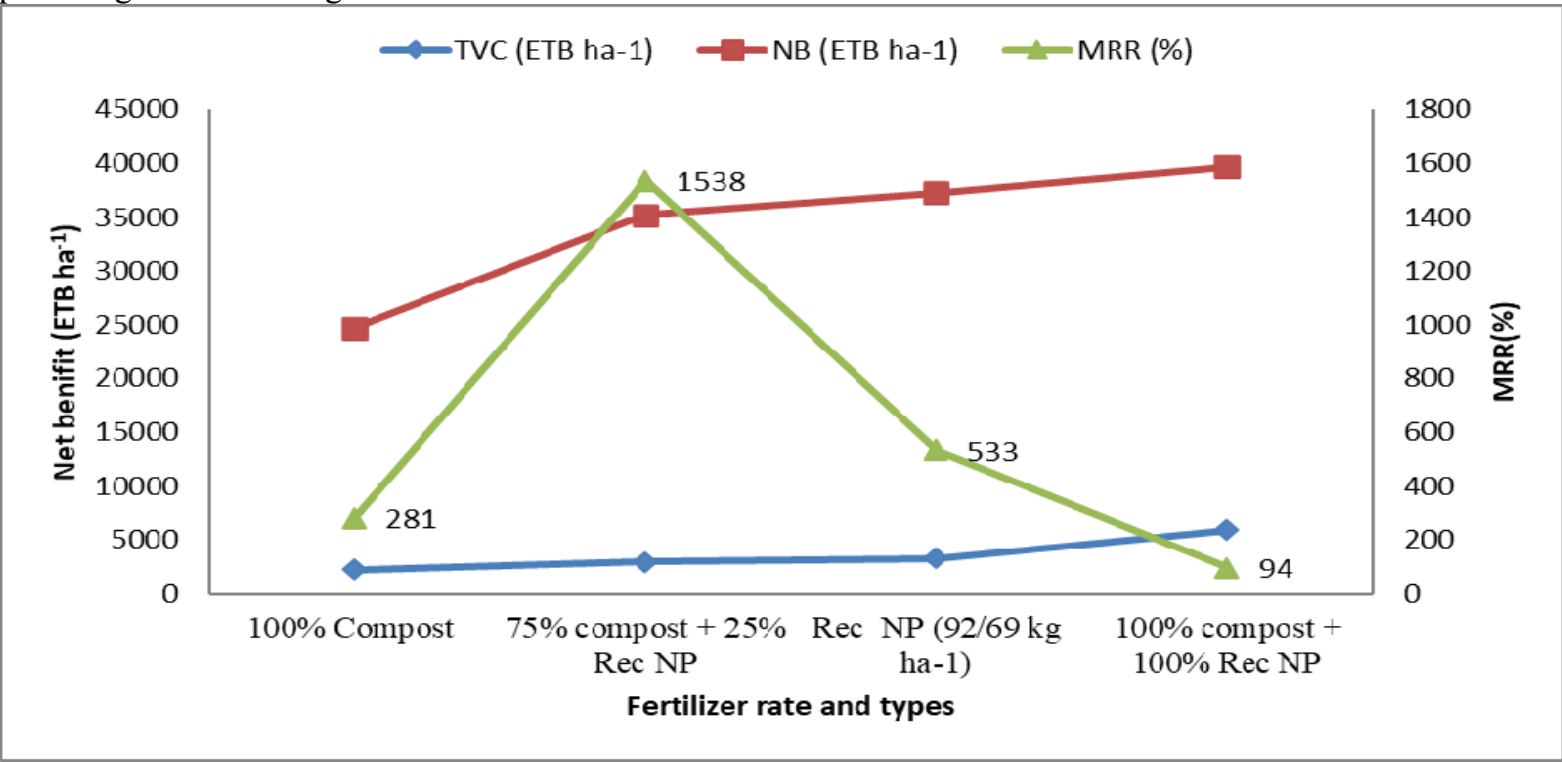

Figure 1 Total variable cost, net benefit and MRR \% of fertilizer rate and types of QPM maize variety at Jimma zone in 2016 and 2017 cropping season 
Market prices are ever changing and as such a recalculation of the partial budget using a set of likely future prices (i.e., sensitivity analysis) was essential to identify treatments which may likely remain stable and sustain satisfactory returns for farmers despite price fluctuations. The sensitivity analysis study indicates an increase in the field price of the total variable costs, and a fall in the price of maize grain, which represented a price variation of $15 \%$.

The price changes are realistic under market conditions prevailing at Jimma area which were above the minimum acceptable MRR of $100 \%$ for application of $100 \%$ Compost $\left(9.2 \mathrm{t} \mathrm{ha}^{-1}\right), 75 \%$ compost $+25 \%$ recommended NP fertilizer and recommended NP fertilizer $\left(92 / 69 \mathrm{~kg} \mathrm{ha}^{-1}\right)$ (Table 5).

Table 5 Sensitivity analysis of maize production based on a $15 \%$ rise in total cost and maize price of gross field benefit fall

\begin{tabular}{llllll}
\hline Treatments & $\begin{array}{l}\text { TVC } \\
\left.\mathrm{ha}^{-1}\right)\end{array}$ & $\begin{array}{l}\text { (ETB } \\
\left(\mathrm{ETB} \mathrm{ha}^{-1}\right)\end{array}$ & $\begin{array}{l}\text { Raised cost } \\
\text { Raised } \\
\text { benefit }\end{array}$ & MRR (\%) \\
\hline Negative Control & --- & 15770 & --- & --- & --- \\
$100 \%$ Compost $\left(9.2 \mathrm{t} \mathrm{ha}^{-1}\right)$ & 2537 & 21034 & 2537 & 5263 & 207 \\
$75 \%$ compost $+25 \% \mathrm{Rec}^{-} \mathrm{NP}$ & 3320 & 29938 & 783 & 8905 & 1137 \\
Rec NP $\left(92 / 69 \mathrm{~kg} \mathrm{ha}^{-1}\right)$ & 3764 & 31685 & 444 & 1747 & 394 \\
\hline
\end{tabular}

*GY= Grain yield; GFB = Gross field benefit; TCV = Total cost that varied; NB = Net benefit; D=Dominated treatment; UD= Un-dominated treatments; Rec=Recommended; ETB = Ethiopian Birr; Price of chemical fertilizer $=13.5$ birr kg${ }^{-1}$; Price of Urea $=10$ birr kg-1 ; Wage rate $=30$ Birr man-day ${ }^{-1}$; Retail price of grain $=6$ birr $\mathrm{kg}^{-1}$

3.4 Validation of QPM Maize variety under Integrated Uses of Different Fertilizer Types in Jimma Zone, southwestern Ethiopia

After 2 years experiment of QPM maize variety evaluation under integrated uses of different fertilizer types, validation of the experiment was done at Jimma zone Omonada woreda. The experiment was done on four farmers' sites for one year during the 2018 main cropping season. The objective of the activity was to determine one optimum integrated use of fertilizer where maximum yield potential of BHQPY545 maize obtained. Four fertilizer rates: 1) $92 / 69 \mathrm{~kg} \mathrm{ha}^{-1} \mathrm{~N} / \mathrm{P}_{2} \mathrm{O}_{5}$, 2) $25 \%$ Compost $+75 \%$ recommended NP fertilizer, 3) 50\% Compost+ $50 \%$ recommended NP and 4) 100\% Compost $+100 \%$ recommended NP fertilizer were selected for further evaluation and validation.

Table 6 Validation of QPM maize variety under integrated uses of different fertilizer types on grain yield and yield components at Omonada woreda, Jimma zone during 2018 cropping season

\begin{tabular}{llll}
\hline Fertilizer types and rates & Plant height $(\mathrm{cm})$ & $\begin{array}{l}\text { Grain yield } \\
\left(\mathrm{kg} \mathrm{ha}^{-1}\right)\end{array}$ & $\begin{array}{l}\text { Above ground biomass } \\
\left(\mathrm{t} \mathrm{ha}^{-1}\right)\end{array}$ \\
\hline $92 / 69 \mathrm{~N} / \mathrm{P}_{2} 0_{5}$ & 254.75 & $7123 \mathrm{~b}$ & $12.35 \mathrm{~b}$ \\
$25 \%$ Compost $+75 \%$ Rec NP & 250.75 & $6789 \mathrm{~b}$ & $11.63 \mathrm{~b}$ \\
$50 \%$ Compost $+50 \%$ Rec NP & 252.75 & $6699 \mathrm{~b}$ & $11.80 \mathrm{~b}$ \\
$100 \%$ Compost $+100 \%$ Rec NP & 262.25 & $8181 \mathrm{a}$ & $13.70 \mathrm{a}$ \\
\hline LSD $(0.05)$ & $\mathrm{NS}$ & 887 & 1.34 \\
$\mathrm{CV}(\%)$ & 12.00 & 7.71 & 6.76 \\
\hline
\end{tabular}

Values followed by the same letter within a column are not significantly different at $\mathrm{P}<0.05$; Rec= Recommended; Compost was applied based on N-equivalence rate of recommended fertilizer rate $\left(92 \mathrm{~N} \mathrm{~kg} \mathrm{ha}^{-1}\right)$

The farmers' perceptions were collected at the green ear stage and at harvest period. Seven maize stand evaluation criteria were set by farmers to decide optimal fertilizer recommendation for BHQPY545 QPM maize variety. Accordingly, maize growth rate, probability of lodging, number of ears/plant and yield potential were found the most important for the maize stand evaluation criteria. Further, based on maize stand evaluation criteria's that was set by farmers (Table 7) $35 \%$ of them chosen for $100 \%$ Compost $+100 \%$ recommended NP fertilizer. 
Table 7 Farmers perception on optimal integrated uses of different fertilizer types at Omonada woreda at 2018 cropping season

\begin{tabular}{|c|c|c|c|c|}
\hline $\begin{array}{l}\text { Farmers Evaluation } \\
\text { Criteria }\end{array}$ & $92 / 69 \mathrm{~N}-\mathrm{P}_{2} \mathrm{O}_{5}$ & $\begin{array}{l}25 \% \quad \text { Compost } \\
+75 \% \text { Rec NP }\end{array}$ & $\begin{array}{l}50 \% \quad \text { Compost }+ \\
50 \% \text { Rec NP }\end{array}$ & $\begin{array}{l}100 \% \text { Compost+ } \\
100 \% \text { Rec NP }\end{array}$ \\
\hline Weeding Frequency & Low & Low & medium & High \\
\hline Growth rate & Slow & slow & Fast & Fast \\
\hline Probability of lodging & medium & medium & medium & Medium \\
\hline Number of ears/plant & 2 & 2 & 2 & $2-3$ \\
\hline Cob size & Medium & Medium & Medium & Bigger \\
\hline Number of ear rotting & medium & medium & low & low \\
\hline Yield potential & Medium & Medium & Medium & Higher \\
\hline choice in Percentage & $25 \%$ & $22 \%$ & $18 \%$ & $35 \%$ \\
\hline
\end{tabular}

In general, from farmer's decision point and current on farm input availability and economic analysis with highest MRR 415\% (Table 8), 92/69 N-P $\mathrm{O}_{5}$ fertilizer application taken as optimal fertilizer application and recommended for production of BHQPY545 in the Waredas and other similar humid agro-ecologies of west and southwest Ethiopia.

Table 8 Partial budget with estimated MRR (\%) for effect of organic and inorganic fertilizer on grain yield of QPM maize variety at Omonada woreda in 2018 cropping season

\begin{tabular}{llllllll}
\hline Fertilizer types and rates & $\begin{array}{l}\text { GY }(\mathrm{kg} \\
\left.\mathrm{ha}^{-1}\right)\end{array}$ & $\begin{array}{l}\text { Adj.GY } \\
\left(\mathrm{kg} \mathrm{ha}^{-1}\right)\end{array}$ & $\begin{array}{l}\text { GFB } \\
\left(\mathrm{ETB} \mathrm{ha}^{-}\right. \\
1)\end{array}$ & $\begin{array}{l}\text { TVC } \\
\left(\mathrm{ETB} \mathrm{ha}^{-}\right. \\
1)\end{array}$ & $\begin{array}{l}\text { NB } \\
\left(\mathrm{ETB} \mathrm{ha}^{-}\right.\end{array}$ & $\begin{array}{l}\text { Domi } \\
\text { nance }\end{array}$ & $\begin{array}{l}\text { MRR } \\
(\%)\end{array}$ \\
\hline $50 \%$ Compost $+50 \%$ Rec NP & 6699 & 6029 & 36173 & 3067 & 33106 & --- & --- \\
$92 / 69 \mathrm{~kg} \mathrm{ha}^{-1} \mathrm{~N} / \mathrm{P} 205$ & 7123 & 6411 & 38467 & 3513 & 34954 & UD & 415 \\
$25 \%$ Compost $+75 \%$ Rec NP & 6789 & 6111 & 36663 & 3577 & 33087 & $\mathrm{D}$ & --- \\
$100 \%$ Compost $+100 \%$ Rec NP & 8181 & 7363 & 44179 & 5443 & 38736 & UD & 196 \\
\hline
\end{tabular}

${ }^{*} \mathrm{GY}=$ Grain yield; GFB = Gross field benefit; TCV = Total cost that varied; NB = Net benefit; $\mathrm{D}=$ Dominated treatment; $\mathrm{UD}=\mathrm{Un}$-dominated treatments; $\mathrm{Rec}=$ Recommended; $\mathrm{ETB}=$ Ethiopian Birr; Price of chemical fertilizer $=13.5$ birr kg${ }^{-1}$; Price of Urea $=10$ birr kg$^{-1}$; Wage rate $=30$ Birr man-day $^{-1}$; Retail price of grain $=6$ birr $\mathrm{kg}^{-1}$

\section{Conclusion and Recommendation}

The results revealed that individual chemical fertilizer and compost improved grain yield and above ground biomass yield of the QPM maize varieties. The improvement was mainly due to availability of nutrients from the chemical fertilizer and compost for plant development up to cob formation. Application of integrated organic and chemical fertilizer increased grain yield and above ground biomass of the crop mainly, due to better grain development and cob formation.

Summary of results from across seasons and sites indicated compost and chemical fertilizer significantly affects the grain and above ground biomass yields of the QPM maize varieties. To increase certainty and further the use of optimum fertilizer, evaluation criteria were set by farmers, and required to choose or reject fertilizer rate and types not technically appropriate. Based on this and economic analysis, $92 / 69 \mathrm{~kg} \mathrm{ha} \mathrm{N}^{-1} \mathrm{~N} / \mathrm{P}_{2} 0_{5}$ fertilizer application taken as optimal fertilizer application and recommended for production of BHQPY545 in Jimma area and other similar agro-ecologies of Ethiopia. Also, application of $75 \%$ compost $+25 \%$ recommended NP fertilizer could be recommended as an alternative for farmers.

\section{References}

Adefris T, Dagne W, Abraham T, Birhanu T, Kassahun B, Dennis F, Prasanna B.M (2015). Quality Protein Maize (QPM): A Guide to the Technology and Its Promotion in Ethiopia. CIMMYT: Addis Ababa, Ethiopia.34p

Adekayode FO, Ogunkoya MO (2010). Effect of quantity and placement distances of inorganic fertilizer in improving soil fertility status and the performance and yield of maize in a tropical rain forest zone of Nigeria. Journal of Soil Science and Environmental Management 1: 155-163.

Amanullah A, Iqbal A, Iqbal M (2015). Impact of potassium rates and their application time on dry matter partitioning, biomass and harvest index of maize with and without cattle dung application. Emirates Journal 
of Food and Agriculture 27: 447-453.

Ayub M, Nadeem MA, Sharar MS, Mahmood N (2002). Response of maize fodder to different levels of nitrogen and phosphorus. Asian Journal of Plant Science 1: 352-354.

Aman J, Kassahun B, Sintayehu A, Tolera B (2016). Evaluation of Quality Protein Maize (Zea mays L) Hybrids at Jimma, Western-Ethiopia. Journal of Forensic Anthropol 1: 101.

Balai ML, Verma A, Nepalia V, Kanthaliya PC (2011). Productivity and quality of maize (Zea mays) as influenced by integrated nutrient management under continuous cropping and fertilization. The Indian Journal of Agricultural Sciences 81: 374-376.

Batjes NH (1995). Aglobal data set of soil pH properties. Technical Paper 27, International Soil Reference and Information Centre (ISRIC), Wageningen.

Berhanu D (1980). A survey of studies conducted about soil resources appraisal and evaluation for rural development in Ethiopia, Addis Ababa.70p.

Brady N, Weil RR (2002). The nature and properties of soils. 13 edn. Prentince Hall. New Jersey, USA. 598p.

Brady N, Weil RR (2008). Nature and Properties of Soils (14th edn.). Prentice Hall, Upper Saddle River. 992p.

Brady NC, Weil RR, Brady NC (2010). Elements of the nature and properties of soils (No. 631.4 B733E.). Upper Saddle River, NJ: Pearson educational international.

Chang C, Sommerfeldt TG, Entz T (1990). Rates of soil chemical changes with eleven annual applications of cattle feedlot manure. Canadian Journal of Soil Science 70: 673-681.

CIMMYT (1988). From Agronomic Data to Farmer Recommendations: An Economics Training Manual. Completely revised edition. Mexico, D.F.79p.

Dagne C (2016). Blended Fertilizers Effects on Maize Yield and Yield components of Western Oromia, Ethiopia. Agriculture, Forestry and Fisheries 5:151-162.

Diacono M, Montemurro F (2010). Long-term effects of organic amendments on soil fertility: A review. Agron Sustain Development 30: 401-422.

Gemechu N, Sentayehu A, Leta T (2016). Review on Quality Protein Maize Breeding for Ethiopia. Journal of Biology, Agriculture and Healthcare 6: 84-96.

Getachew A, Taye B (2005). On-farm integrated soil fertility management in wheat on nitisols of central Ethiopian highlands. Ethiopian Journal of Natural Resources 7: 141-155.

Gomez KA, Gomez AA (1984). Statistical procedures for agricultural research. 2nd ed. John Wiley \& Sons, New York, NY.

Kogbe JOS, Adediran JA (2003). Influence of nitrogen, phosphorus and potassium application on the yield of maize in the savanna zone of Nigeria. African Journal of Biotechnology 2: 345-349.

Leta T, Mosisa W, Gelana S, Jemal A, Hadji T, Sewagegne T, Twumasi-Afriyie S (2001). Enhancing the Contribution of Maize to Food Security in Ethiopia. Proceedings of the Second National Maize Workshop of Ethiopia 12-16 November 2001. Addis Ababa, Ethiopia. pp.39-45.

Makinde EA, Ayoola OT (2010). Growth, yield and NPK uptake by maize with complementary organic and inorganic fertilizers, African Journal of Food, Agriculture, Nutrition and Development 10:2203-2217.

Marschner P (2012). Rhizosphere biology. In: Marschner's Mineral Nutrition of Higher Plants (Third Edition), Elsevier publisher. pp. 369-388.

Mugwe J, Mugendi D, Kungu J, Mucheru-Muna M (2007). Effects of plant biomass, manure and inorganic fertilizer on maize yield in the Central Highlands of Kenya. African Crop Science Journal 15: 111-126.

N'Dayegamiye A, Nyiraneza J, Chantigny H, Laverdiere R (2010). Long-term manure application and forages reduce nitrogen fertilizer requirements of silage corn-cereal cropping systems. Agronomy Journal 102: $1244-1251$.

Ngwira AR, Nyirenda M, Taylor D (2013). Toward sustainable agriculture: An evaluation of compost and inorganic fertilizer on soil nutrient status and productivity of three maize varieties across multiple sites in Malawi. Agroecology and Sustainable Food Systems 37: 859-881.

Onasanya RO, Aiyelari OP, Onasanya A, Oikeh S, Nwilene FE, Oyelakin OO (2009). Growth and yield response of maize to different rates of nitrogen and phosphorus fertilizers in southern Nigeria. World Journal of Agricultural Sciences 5: 400-407.

Onwudiwe N, Benedict OU, Ogbonna PE, Ejiofor EE (2014). Municipal solid waste and NPK fertilizer effects on soil physical properties and maize performance in Nsukka, Southeast Nigeria. African Journal of Biotechnology 13: 68-75.

Rahman MA, Rahman MM, Begum MF, Alam MF (2012). Effect of bio compost, cow dung compost and NPK fertilizers on growth, yield and yield components of chilli. International Journal of Biosciences 2: 51-55.

Rao S, Singh KK, Ali M (2001). Sulfur: A key nutrient for higher pulse production. Fertilizer News 46: $37-50$.

Ravi N, Basavarajappa R, Chandrashekar CP, Harlapur SI, Hosamani MH, Manjunatha MV (2012). Effect of integrated nutrient management on growth and yield of quality protein maize. Journal of Agricultural Sciences 25: 395-396. 
Tekalign M, Haque I (1991). Phosphorus status of some Ethiopian soils, II. Forms and distribution of inorganic phosphates and their relation to available phosphorus. Tropical Agriculture 68: 2-8.

Twumasi-Afriye S, Palacios Rojas N, Friesen D, Teklewold A, Gissa DW, De Groote H, Prasanna BM (2016). Guidelines for the quality control of Quality Protein Maize seed and grain. CIMMYT, Ethiopia. 38p.

Vanlauwe B (2002). Integrated plant nutrient management in sub-Saharan Africa: from concept to practice. CABI. 355p.

Yayock JY, Lombin G, Owonubi JJ (1988). Crop science and production in warm climates. Macmillan publishers, London. $314 \mathrm{p}$ 